BHUMI: Jurnal Agraria dan Pertanahan

Received: May 7, 2021; Reviewed: 17 May, 2021; Accepted: November 8, 2021.

To cite this article: Idawijayanti, T \& Pramono, RWD. (2021). Pengadaan Tanah Jalur Kereta Api Bandara Adi Soemarmo-Solo Balapan: Kebijakan Konservasi Vs Pembangunan Infrastruktur, Bhumi, Jurnal Agraria dan Pertanahan, 7 (2), 163-180.

DOI: 10.31292/bhumi.v7i2.484

Copyright: (C2021 Tri Idawijayanti, Retno Widodo Dwi Pramono. All articles published in Jurnal Bhumi are licensed under a Creative Commons Attribution-ShareAlike 4.o International license.

Research Article

\title{
PENGADAAN TANAH JALUR KERETA API BANDARA ADI SOEMARMO- SOLO BALAPAN: KEBIJAKAN KONSERVASI VS PEMBANGUNAN INFRASTRUKTUR
}

\author{
Tri Idawijayanti ${ }^{*}$ \& Retno Widodo Dwi Pramono ${ }^{2}$ \\ Sekolah Tinggi Pertanahan Nasional \\ ${ }^{2}$ Departemen Teknik Arsitektur dan Perencanaan, Universitas Gadjah Mada \\ *Koresponden E-mail: triidawijayanti@gmail.com
}

\begin{abstract}
Dilemmas and conflicts frequently arise during public policy-making. For instance, those occurring between the Policy for the Protection of Sustainable Food Agricultural Land $\left(\mathrm{PLP}_{2} \mathrm{~B}\right)$ and land acquisition for development in the public interest (PTPKU). The former aims to preserve agricultural land, whereas the latter ensures absolute land provision for infrastructure and facility development in the public interest. The purpose of this study is to describe the policy conflicts that exist between the PLP2B policy and the PTPKU policy. A qualitative approach is used to conduct this research with a case study design using content analysis. Apart from documents, data triangulation is also conducted through interviews with multiple parties involved in decision-making and through observation and documentation of field conditions. Although both are in the public interest, the study's findings indicate that conservation is inferior to infrastructure development. The process of nullifying conservation implementation goes through a series of steps that emerge at each stage of land acquisition justification.
\end{abstract}

Key words: Boyolali-Indonesia, LP2B, Land Acquisition, Policy Conflicts, Spatial Planning

Intisari: Dilema dan konflik sering terjadi dalam pengambilan kebijakan publik. Sebagai contoh yaitu antara kebijakan Perlindungan Lahan Pertanian Pangan Berkelanjutan (PLP2B) dan kebijakan Pengadaan Tanah bagi Pembangunan untuk Kepentingan Umum (PTPKU). Kebjiakan PLP2B bertujuan untuk mempertahankan tanah pertanian, sedangkan kebijakan PTPKU menjamin penyediaan lahan secara mutlak bagi pembangunan infrastruktur atau fasilitas bagi kepentingan publik. Penelitian ini bertujuan untuk menggambarkan konflik pada dua contoh kebijakan di atas. Penelitian ini menggunakan pendekatan kualitatif, dengan desain studi kasus menggunakan konten analisis (content analysis). Selain berdasar dokumen, dilakukan juga trianggulasi dalam penggunaan data, yaitu dengan wawancara terhadap beberapa pihak yang terlibat dalam pengambilan keputusan, serta observasi dan dokumentasi kondisi lapangan. Dari hasil penelitian tergambar bahwa meski sama-sama sebagai kepentingan umum, kebijakan pelestarian pertanian kalah dengan kepentingan umum pembangunan infrastruktur. Proses pembatalan ketetapan pelestarian terjadi melalui berbagai tahap yang ada pada setiap tahap justifikasi pelaksanaan pengadaan tanah.

Kata Kunci: konflik kebijakan, Tata Ruang, LP2B, Pengadaan Tanah, Boyolali-Indonesia 


\section{A. Pendahuluan}

Konflik merupakan suatu fenomena yang mendasari studi politik dan kebijakan publik yang menghasilkan efek umpan balik pada pengaturan kebijakan (Weible \& Heikkila, 2017). Konflik muncul ketika kebijakan saling berpengaruh dan menjadikan ancaman bagi kebijakan yang lain. Dalam hal praktek penataan ruang di Indonesia misalnya, pertentangan antara Kebijakan Perlindungan Lahan Pertanian Pangan Berkelanjutan (PLP2B) dan kebijakan pengadaan tanah. Yang pertama tercermin dalam UU No 41 Tahun 2009 tentang Perlindungan Lahan Pertanian Pangan Berkelanjutan yang bertujuan mempertahankan tanah pertanian sedangkan yang kedua tercermin dalam UU No.2 Tahun 2012 tentang Pengadaan Tanah Bagi Pembangunan untuk Kepentingan Umum yang bertujuan menjamin penyediaan lahan secara mutlak bagi pembangunan infrastruktur atau fasilitas bagi kepentingan publik. Berdasarkan hasil penelitian oleh Nasoetion dalam Iqbal dkk. (2007) pertentangan ini merupakan penyebab terjadinya konversi lahan pertanian selain akibat dari sulitnya mendapatkan kerelaan dari pemilik lahan atau kemampuan pembayaran kompensasi sesuai dengan konsep opportunity cost (Aprildahani dkk., 2017; Palupi, 2017; Rachmadiansyah, 2019).

Berdasar penelitian Nasution tersebut dapat dikatakan bahwa ancaman terhadap $\mathrm{LP}_{2} \mathrm{~B}$ dapat datang dari kebijakan pemerintah sendiri, misalnya dari bobot urgensi yang diberikan pemerintah terhadap pembangunan infrastruktur dalam rangka mendorong investasi untuk pertumbuhan ekonomi. Fakta ini serupa dengan hasil penelitian Hakim (2016) yang mengungkap bahwa dalam pemanfaatan ruang yang tujuannya untuk pembangunan ekonomi berdampak pada konversi lahan.

Banyak praktik terjadi seperti di Kabupaten Boyolali, berdasarkan data dari Kantor Pertanahan Kabupaten Boyolali, Pengadaan tanah jalur kereta api dan jalan tol ruas Boyolali-Yogyakarta mengenai lahan pertanianyang ditetapkan menjadi LP2B berdasarkan Perda No. 17 Tahun 2016 tentang Perlindungan Lahan Pertanian Pangan Berkelanjutan (Perda 17/2016). Sering terjadi pemerintah daerah mengubah atau bahkan melanggar kebijakan yang telah ada terlebih dahulu tentang LP2B dan mengalihfungsikan lahan pertanian tersebut karena terdapat program pembangunan untuk kepentingan umum (Ayu \& Heriawanto, 2018; Syifa, 2017; Zulfikar, 2017). Pembangunan untuk kepentingan umum yang dilakukan melalui mekanisme pengadaan tanah didasarkan pada UU No.2 Tahun 2012 dapat memaksa siapa saja untuk menfasilitasi pengadaan tanah untuk kepentingan umum. Namun demikian terungkap juga oleh Lisdiyono (2014) bahwa alih fungsi lahan pertanian sebenarnya juga merupakan dilema bagi pemerintah, disatu sisi program pembangunan ekonomi harus sukses, namun pemerintah juga berharap kedaulatan pangan dan kualitas lingkungan terjaga. Dalam konteks dilematis ini, implementasi kebijakan menimbulkan konflik, sebagaimana diungkap oleh (Nugrahani, 2019) bahwa dilema dan ambiguitas adalah salah satu faktor terjadinya konflik kebijakan. Faktor lainnya adalah adanya peraturan yang masih abu-abu (Anggalini, 2018), perbedaan pandangan dalam melihat kebijakan (Matland, 1995) dan benturan kepentingan antar sektor (A. L. Hakim dkk., 2017), serta kecenderungan keberpihakan pada peningkatan pendapatan asli daerah (Amiludin, 2018; Aminah, 2015; Lisdiyono, 2008)

Byrne, dkk (2007) menyatakan bahwa dalam konflik kebijakan terdapat hubungan antara politik dan pembuat (aktor) kebijakan dalam menentukan strategi kebijakan untuk memilih kepentingan ekonomi atau lingkungan. Pembuat kebijakan ini adalah pemerintah, yang dalam sistem pemerintahan Indonesia adalah Presiden. Presiden yang menentukan strategi politik yang digunakan untuk menjalankan pemerintahan di Indonesia yang dalam implementasinya dibantu oleh para kepala daerah.

Salah satu contoh untuk mengungkap bagaimana suatu konflik kebijakan antara pelestarian lahan pertanian dengan pembangunan infrastruktur ekonomi yang terjadi adalah kasus pengadaan tanah untuk pembangunan rel kereta api di Kabupaten Boyolali. Berdasarkan data dari Kantor Pertanahan Kabupaten Boyolali, pengadaan tanah pembangunan jalur kereta api akses Bandara Adi Soemarmo lintas Solo Balapan sepanjang 7,25 km mengenai bidang tanah yang sebagian besar berupa hamparan 
sawah produktif dan masuk dalam kawasan PLP2B yang telah ditetapkan sebagai Perda pada tahun 2016. Penelitian ini bertujuan menggambarkan pola konflik kebijakan yang terjadi antara kebijakan PLP2B dan kebijakan pengadaan tanah untuk kepentingan umum dan menggambarkan proses terjadinya perubahan-perubahan kebijakan terkait.

\section{B. Metode}

Penelitian berupa studi kasus dengan pendekatan kualitatif. Sebagaimana dijelaskan Cresswell (2009) yaitu "metode untuk mengeksplorasi dan memahami masalah yang berkaitan dengan sosial dan kemanusiaan". Strategi dilakukan dengan mengidentifikasi kasus yang terikat oleh waktu dan tempat dengan menggunakan berbagai sumber informasi sehingga memberikan gambaran yang terperinci dan mendalam. Dalam hal ini peneliti mengembangkan analisis mendalam terhadap proses penetapan $\mathrm{LP}_{2} \mathrm{~B}$ untuk tujuan konservasi dan proses pengambilan keputusan yang membiarkan LP2B terkonversi dalam rangka kepentingan umum.

Data utama adalah dokumen-dokumen kebijakan publik yang kemudian didalami maknanya melalui wawancara, observasi, dan dokumentasi terhadap kondisi lapangan. Wawancara dilakukan terhadap Kantor Pertanahan Kab. Boyolali, Dinas Pertanian Kab. Boyolali, BP 3 D Kab. Boyolali, Pemerintah desa dan masyarakat yang dipilih secara purposive mewakili orang-orang yang paling terlibat dalam proses pengambilan keputusan. Wawancara dilakukan mengunakan pedoman wawancara yang dalam pelaksanaannya bisa dikembangkan oleh peneliti berdasar situasi proses wawancara untuk menggali informasi lebih lanjut.

Analisis data dengan menggunakan content analysis (analisis isi). Sumardjono dalam Dewi (2019) mengemukakan bahwa "content analysis" adalah "teknik yang digunakan untuk menarik kesimpulan melalui pesan (dari dokumen, hasil wawancara, pengamatan) yang dilakukan berdasarkan metode ilmiah (logis-sistematis)". Analisis ini digunakan untuk menarik kesimpulan dari dokumen maupun pernyataan hasil wawancara secara sistematik dengan memilah kata-kata dalam jumlah besar menjadi sejumlah katakata yang dikategorisasi sesuai dengan koding yang dikehendaki. content analysis (analisis isi) diawali terhadap pasal-pasal dalam dokumen kebijakan yang mempengaruhi terjadinya berbagai keputusan yang didalamnya terdapat konflik kebijakan. Kriteria untuk menyatakan bahwa kebijakan tersebut mengarah adanya konflik adalah adanya pertentangan tujuan antara kebijakan yang satu dengan yang lainnya. Selanjutnya, dalam menjaga validitas dilakukan triangulasi dengan mengkonfirmasi makna penyataan dalam dokumen melalui wawancara serta mengecek kondisi lapangan melalui observasi dan dokumentasi.

\section{Hasil dan Pembahasan}

\section{Proses Penetapan Kebijakan PLP2B di Kabupaten Boyolali}

Dalam RPJMN Kabupaten Boyolali, salah satu misi pembangunan Kabupaten Boyolali tahun 20162021 adalah menjadi lumbung padi dan pangan nasional. Hal ini merupakan upaya dalam menjaga kemandirian, ketahanan, dan kedaulatan pangan nasional dari adanya fenomena berkurangnya lahan pertanian yang cukup pesat dari tahun ke tahun. Fenomena ini tergambar pada Tabel 1 dibawah ini dalam kurun waktu 5 tahun.

Tabel 1. Luas Penggunaan Tanah di Kabupaten Boyolali Tahun 2015-2019

\begin{tabular}{lllllll}
\hline \multirow{2}{*}{ Tahun } & \multicolumn{3}{c}{ Tanah Sawah (Ha) } & \multicolumn{3}{c}{ Tanah Non Sawah (Ha) } \\
\cline { 2 - 7 } & Irigasi & Non Irigasi & Total & $\begin{array}{c}\text { tegalan/ } \\
\text { kebun }\end{array}$ & $\begin{array}{c}\text { Pekarangan/ Permukiman, } \\
\text { Hutan dan lainnya }\end{array}$ & total \\
\hline 2019 & 11563 & 10827 & 22390 & 29326 & 49794 & 79120 \\
\hline 2018 & 12181 & 10512 & 22693 & 30145 & 48672 & 78817 \\
\hline
\end{tabular}




\begin{tabular}{lllllll}
\hline \multirow{2}{*}{ Tahun } & \multicolumn{3}{c}{ Tanah Sawah (Ha) } & \multicolumn{3}{c}{ Tanah Non Sawah (Ha) } \\
\cline { 2 - 7 } & Irigasi Non Irigasi & Total & $\begin{array}{c}\text { tegalan/ } \\
\text { kebun }\end{array}$ & $\begin{array}{c}\text { Pekarangan/ Permukiman, } \\
\text { Hutan dan lainnya }\end{array}$ & total \\
\hline 2017 & 12991 & 9787 & 22778 & 29840 & 48892 & 78732 \\
\hline 2016 & 12991 & 9787 & 22778 & 29840 & 48892 & 78732 \\
\hline 2015 & 13402 & 9376 & 22778 & 29840 & 48892 & 78732 \\
\hline
\end{tabular}

Sumber: Badan Pusat Statistik, 2020.

Pada tanggal 17 Oktober 2016 Pemerintah Kabupaten Boyolali menetapkan Perda 17/2016. Isi pokok dari perda ini adalah menetapkan luasan $\mathrm{LP}_{2} \mathrm{~B}$ dan $\mathrm{LCP} 2 \mathrm{~B}$ secara spasial dalam rangka melindunggi lahan pertanian pangan dari alih fungsi lahan di Kabupaten Boyolali sehingga tercapai kemandirian, kedaulatan dan ketahanan pangan. Hal ini berkesesuaian dengan Pasal 4 ayat (1) huruf g Perda No.9 Tahun 2011 tentang RTRW Kabupaten Boyolali Tahun 2011-2031 menyatakan bahwa salah satu strategi penataan ruang wilayah kabupaten adalah penetapan kawasan LP2B dalam pengendalian dan pemanfaatan lahan pertanian.

Proses penetapan Perda 17/2016 dapat dilihat pada gambar dibawah ini:

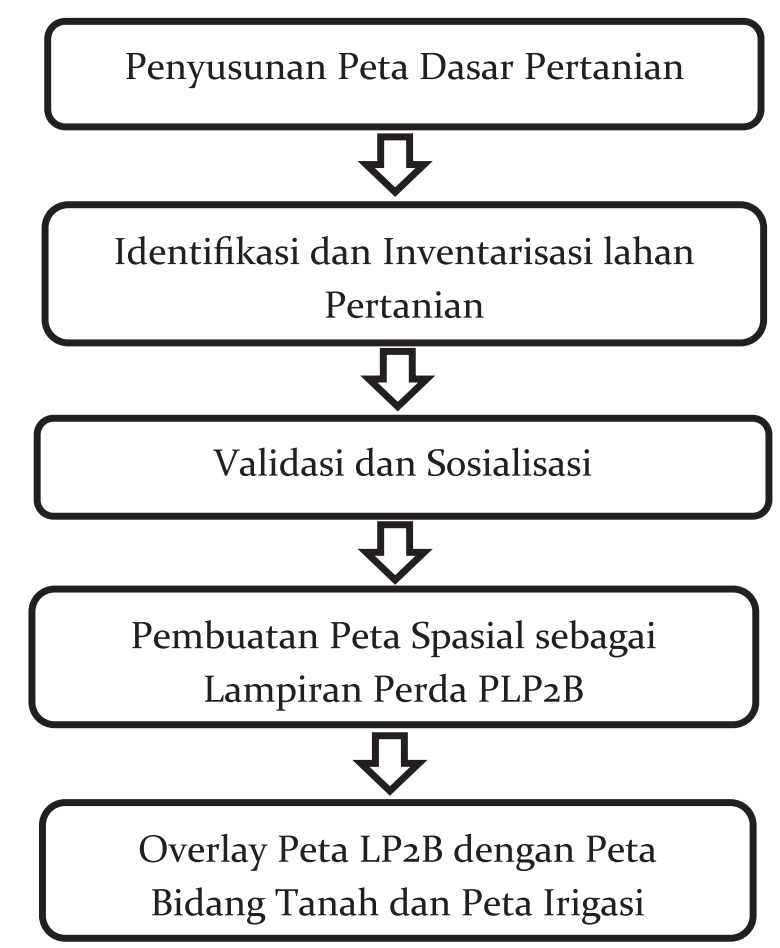

Gambar 1. Proses penetapan Perda 17/2016

Sumber: Dinas Pertanian Kabupaten Boyolali, 2020.

a. Kegiatan pertama adalah penyusunan peta dasar pertanian. Peta dasar ini memuat semua lahan pertanian baik berupa sawah dan tegalan. Penyusunan peta dasar ini dilakukan melalui interpretasi citra.

b. Kegiatan kedua adalah identifikasi dan inventarisasi lahan pertanian. Dengan berdasarkan pada peta dasar maka dilakukan identifikasi dan inventarisasi data di lapangan. Pada tahap ini, kegiatan inventarisasi dan identifikasi lahan yang memenuhi kriteria yang telah ditetapkan dengan melakukan survey langsung di Lapangan. Kegiatan ini dilakukan secara bertahap, yaitu tahap pertama dilakukan pada tahun 2012 meliputi 4 kecamatan (yaitu kecamatan Simo, Sambi, Ngemplak dan Nogosari) dan tahap kedua dilakukan tahun 2015 meliputi 15 kecamatan (yaitu Kecamatan Selo, Ampel, Cepogo, Musuk, Boyolali, Mojosongo, Teras, Banyudono, Sawit, Klego, Andong, Karanggede, Wonosegoro, Kemusu dan Juwangi). 
Dalam mengidentifikasi dan menginventarisasi lahan pertanian menjadi $\mathrm{LP}_{2} \mathrm{~B}$ dan $\mathrm{LCP}_{2} \mathrm{~B}$ harus berpedoman pada kriteria lahan pertanian dalam Pasal 22 ayat (1) PP No. 1 Tahun 2011 tentang Penetapan dan Alih fungsi LP2B antara lain:

"berada pada kesatuan hamparan lahan yang mendukung produktivitas dan efisiensi produksi, memiliki potensi teknis dan kesesuaian lahan yang sangat sesuai, sesuai, atau agak sesuai untuk peruntukan pertanian pangan, didukung infrastruktur dasar; dan/atau telah dimanfaatkan sebagai lahan pertanian pangan”.

Dalam pelaksanaan penetapan PLP2B Kabupaten Boyolali, pemerintah daerah tidak berpedoman pada Permentan No. 7 Tahun 2012 tentang Pedoman Teknis, Kriteria dan Persyaratan Kawasan, Lahan dan LCP2B (Permentan 7/2012). Hal ini dikarenakan lahan sawah di Kabupaten Boyolali hampir semua dapat dimasukkan dalam $\mathrm{LP}_{2} \mathrm{~B}$, sedangkan luasan $\mathrm{LP}_{2} \mathrm{~B}$ dan $\mathrm{LCP}_{2} \mathrm{~B}$ yang akan ditetapkan telah ditentukan luasannya dalam RTRW. Untuk itu digunakan kriteria teknis tersendiri berupa:

1) Ketinggian kurang dari $1.000 \mathrm{mdpl}$

2) Kelerengan lahan $3-15 \%$

3) Kedalaman efektif lapisan tanah diatasnya lebih dari $90 \mathrm{~cm}$

4) Curah hujan antara $1.500-4.000 \mathrm{~mm} /$ tahun.

5) Status Irigasi (Irigasi Teknis)

6) Indeks Pertanaman minimal 2 kali tanam.

7) Produktivitas 4,5 ton per hektar atau lebih

Kriteria tersebut ditetapkan dalam rangka memilah lahan sawah yang mempunyai kualitas lebih tinggi dari standar yang ditetapkan dalam Permentan 7/2012.

c. Kegiatan ketiga adalah validasi sekaligus sosialisasi lahan pertanian yang telah diidentifikasi. Kegiatan ini dilaksanakan tahun 2015, dengan hasil kepala desa menyetujui ditetapkannya lahan pertanian yang memenuhi syarat dan kriteria menjadi LP2B dan LCP2B. Pelaksanaan validasi dan sosialisasi dilakukan hanya terhadap kepala desa. Pada waktu kegiatan validasi, kepala desa diminta untuk memberikan saran/masukan akan layak tidaknya sawah untuk ditetapkan menjadi LP2B, akan tetapi dari semua desa yang diberi kesempatan hanya 1 (satu) desa yang memberikan tanggapan ke dinas Pertanian.

d. Kegiatan keempat adalah pembuatan peta spasial yang memuat data hasil validasi kegiatan inventarisasi dan identifikasi bidang tanah yang memenuhi syarat dan kriteria sebagai LP2B. Peta ini kemudian menjadi lampiran dalam Perda 17/2016.

e. Kegiatan kelima melengkapi peta spasial lahan $\mathrm{LP}_{2} \mathrm{~B}$ dengan peta bidang tanah. Kegiatan ini dilakukan pada tahun 2017-2018 dengan mengoverlaykan peta LP2B tahun 2016 dengan peta bidang tanah dan juga peta irigasi. Hasil overlay adalah peta dengan atribut subjek dan objek, sehingga peta LP2B yang baru tersebut dapat memberikan informasi nama pemilik tanah dan letak bidang tanah (by name by address). Hal ini dimaksudkan guna mendukung kebijakan pemberian insentif terhadap lahan yang telah ditetapkan menjadi LP2B. Peta $\mathrm{LP}_{2} \mathrm{~B}$ yang telah dilengkapi dengan peta bidang tanah hanya diberikan kepada instansi pemerintah yang terkait dalam tim Koordinasi Penataan Ruang Daerah (TKPRD) Kabupaten Boyolali. Apabila masyarakat ingin mengetahui informasi mengenai status tanahnya, dapat mengajukan permohonan informasi tata ruang.

Berdasarkan pada kriteria dan pertimbangan tersebut di Kabupaten Boyolali luas LP2B telah ditetapkan sebesar 16.500,990 Ha dan luas LCP2B sebesar 4.193,007 Ha sehingga total luas PLP2B Kabupaten Boyolali adalah 20.693,997 Ha. Gambar dibawah ini merupakan PLP2B di Kabupaten Boyolali berdasarkan Perda 17/2016. 


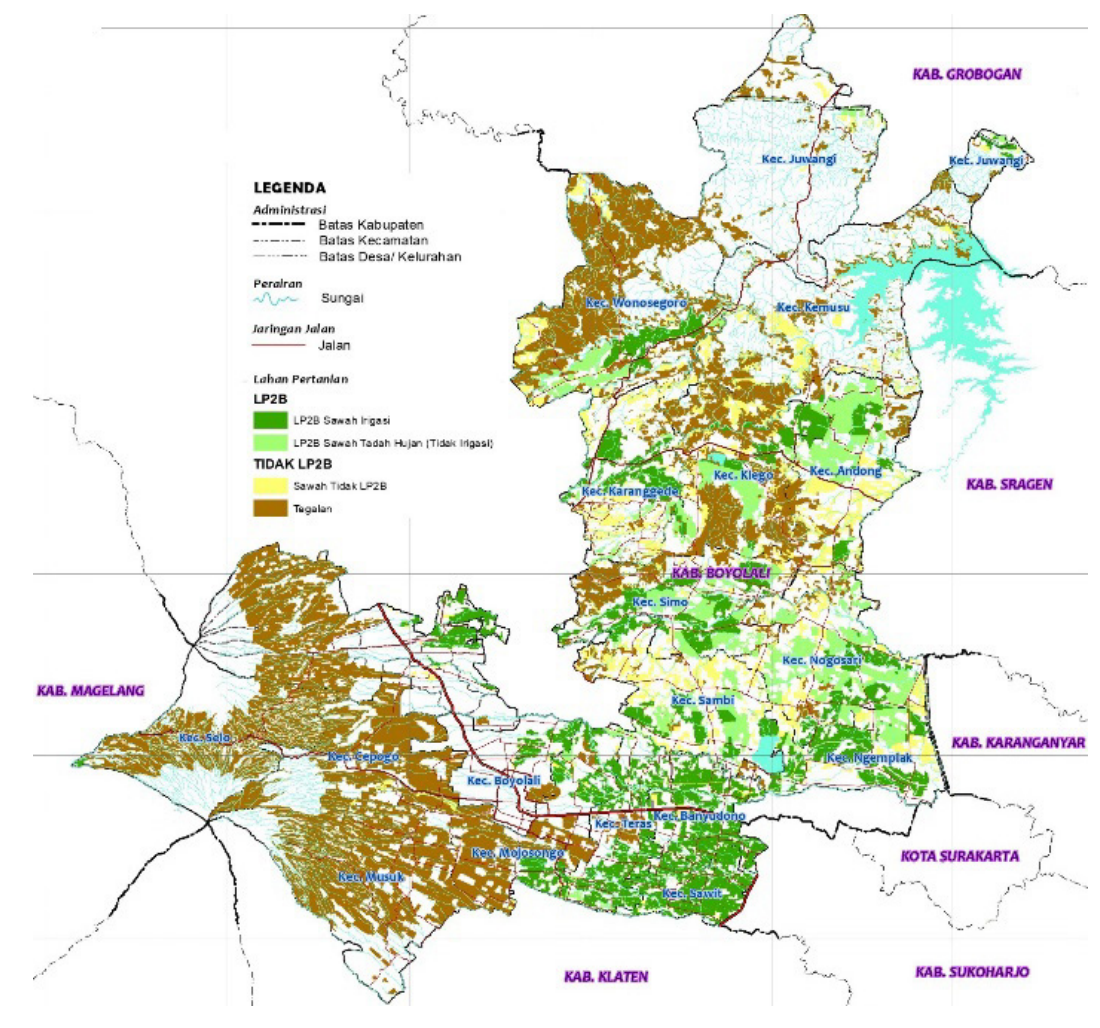

Gambar 2 Peta PLP2B berdasarkan Perda Kab.Boyolali No. 17 Tahun 2016 Sumber: Dinas Pertanian Kabupaten Boyolali, 2020.

\section{Upaya Implementasi Kebijakan PLP2B di Kabupaten Boyolali}

Strategi implementasi kebijakan pengendalian perubahan penggunaan lahan pertanian ditetapkan melalui pemberian insentif dan disinsentif, mekanisme perizinan, proteksi dan penyuluhan kepada masyarakat. Pasal 30 Perda PLP2B menguraikan insentif yang diberikan berupa:

"Bantuan keringanan PBB, pengembangan infrastruktur pertanian, pembiayaan penelitian dan pengembangan benih dan varietas unggul, kemudahan dalam mengakses informasi dan teknologi, penyediaan sarana produksi pertanian, bantuan dana penerbitan sertipikat hak atas tanah pada Lahan Pertanian Pangan Berkelanjutan, dan penghargaan bagi Petani berprestasi tinggi".

Kebijakan insentif untuk pelestarian lahan LP2B ditindaklanjuti dengan Peraturan Bupati Boyolali No. 10 Tahun 2018 (Perbub 10/2018). Berdasarkan hasil wawancara dengan Dinas pertanian Kabupaten Boyolali, diperoleh informasi bahwa berdasarkan Perbup 10/2018 telah dilakukan bantuan keringanan Pajak Bumi dan Bangunan Perkotaan dan Perdesaan (PBB-P2) pada LP2B beririgasi teknis sebesar 9o\% dari nilai pajak terutang dan dengan ketentuan kepemilikan lahan maksimal 5.ooo meter persegi. Apabila luasan lahan per bidang lebih dari 5.000 meter persegi, maka wajib pajak membayar penuh atas kelebihan luasan per bidang tersebut. Selain itu, dalam merealisasikan insentif berupa bantuan dana penerbitan sertipikat HAT, Pemerintah Daerah bekerja sama dengan Kantor Pertanahan Kabupaten Boyolali dengan memberikan sertipikat pada pemilik lahan $\mathrm{LP}_{2} \mathrm{~B}$ yang belum memiliki sertipikat sebanyak 150 bidang yang tersebar di Kecamatan Sawit, Klego dan Banyudono. Dalam hal pemberian bantuan infrastruktur, meskipun bantuan infrastruktur pertanian maupun sarana produksi tidak dikhususkan untuk pemilik lahan $\mathrm{LP}_{2} \mathrm{~B}$, namun telah banyak bantuan yang diberikan kepada kelompok tani maupun gapoktan, baik dari APBD maupun APBN. Hal ini yang menjadikan bantuan infrastruktur masih bersifat umum, tidak dilakukan dalam rangka pemberian insentif. Akibatnya masyarakat beranggapan bahwa $\mathrm{LP}_{2} \mathrm{~B}$ 
bukan suatu yang istimewa dan masyarakat tidak memiliki motivasi untuk mempertahankan lahannya untuk menjadi LP2B.

Meskipun telah ada beberapa aksi pemerintah didasarkan pada Perda 17 /2016 dan Perbub 10/2018 pada kenyataannya masih terjadi alih fungsi lahan sawah. Berdasarkan data BPS dalam kurun waktu 3 (tiga) tahun setelah perda ini ditetapkan masih terjadi alih fungsi tanah sawah sebesar $388 \mathrm{Ha}$. Salah satu penyebabnya adalah alih fungsi lahan untuk pembangunan infrastruktur dalam konteks kepentingan umum sebesar 298,57 Ha.

\section{Kebijakan Alih Fungsi LP2B Dalam Rangka Pengadaan Tanah untuk Kepentingan Umum di Kabupaten Boyolali}

Berdasarkan fenomena yang ada, salah satu kejadian penting yang mengkonversi LP2B yang telah ditetapkan adalah adanya kebijakan pengadaan tanah dalam rangka menyediakan tanah untuk pembangunan infrastruktur. Jenis infrastruktur yang akan dibangun sebagian telah ditetapkan dalam RTRW Kabupaten Boyolali tahun 2011-2031 dalam wujud indikasi program rencana pembangunan jalan tol Semarang-Solo dengan panjang 75,8o km, Jogya-Solo dengan panjang 40,495 km dan Solo-Mantingan dengan panjang 56,10 km, rencana induk pengembangan Bandara Internasional Adi Soemarmo tahun 2009-2018, pengembangan prasarana transportasi kereta api komuter, pengembangan kawasan strategis dengan prioritasnya kawasan Surakarta, Boyolali, Sukoharjo,. Karanganyar, Wonogiri, Sragen, dan Klaten (Subosukawonosraten), pengembangan kawasan agropolitan dan minapolitan. Beberapa rencana tersebut juga merupakan program strategis nasional (PSN) antara lain program rencana pembangunan jalan tol Semarang-Solo, Jogya-Solo dan Solo-Mantingan dan pengembangan prasarana transportasi kereta api komuter. Pengertian PSN berdasarkan Pasal 1 angka (1) Perpres No.3 Tahun 2016 tentang Percepatan Pelaksanaan Proyek Strategis Nasional (Perpres 3/2016) adalah proyek "yang memiliki sifat strategis untuk peningkatan pertumbuhan dan pemerataan pembangunan dalam rangka meningkatkan kesejahteraan masyarakat dan pembangunan daerah".

Rencana pembangunan infrastruktur yang telah dituangkan dalam RTRW Kabupaten merupakan program yang akan dilaksanakan sesuai dengan prioritasnya, karena hal tersebut merupakan komitmen pemerintah daerah dalam mewujudkan pembangunan daerah sesuai visi dan misinya. Apalagi rencana pembangunan tersebut menjadi bagian rencana pembangunan nasional. Pada saat ini pembangunan infrastrukturyang merupakan PSN dipercepat pelaksanaannya dan diberi kemudahan melalui kebijakan kebijakan presiden. Salah satu kebijakan tersebut adalah Perpres 3/2016, yang mengalami perubahan 3 (tiga) kali, menjadi Perpres No.58 Tahun 2017, Perpres No.56 Tahun 2018 dan Perpres No.109 Tahun 2020. PSN merupakan kepentingan umum dalam mewujudkan kesejahteraan melalui pembangunan pembangunan infrastruktur. Apabila pengadaan tanah mengenai LP2B maka berlaku ketentuan UUPLP2B, yang membolehkan alih fungsi untuk kepentingan umum. Berdasarkan hasil wawancara dengan Pejabat Kantor Pertanahan Kabupaten Boyolali tentang persepsi kegiatan pengadaan tanah pada $\mathrm{LP} 2 \mathrm{~B}$ diperoleh informasi:

"Dengan adanya program PSN, kabupaten/kota tidak bisa menghindar, sedangkan dilain pihak lahan baku sawah tidak boleh berkurang, harus ada lahan penggantinya, sehingga hal ini menjadi dilema bahwa kebijakan yang dikeluarkan dan kelengkapannya tidak sebanding dengan penegakannya. Kecenderungan kebijakan penataan ruang yang mengacu pada posisi yang lebih tinggi, dalam RDTR kadang tidak sinkron $\mathrm{LP}_{2} \mathrm{~B}$ semakin dikalahkan dengan kepentingan daerah."

Berdasarkan hasil wawancara dengan pejabat dinas pertanian Kabupaten Boyolali diperoleh informasi: 
"Alih fungsi lahan pada $L_{2} B$ dilarang, kecuali untuk kepentingan umum. Apalagi proyek berkaitan dengan PSN. Dalam pengadaan tanah, permasalahannya kadang tidak diperhatikan infrastruktur yang ada disitu, jaringan irigasi terpotong tol, dulu pernah dibuat semacam saluran irigasi dengan diameter $60 \mathrm{~cm}$ sepanjang tol, sekarang ada sampah, lumpur, bagaimana cara membersihkannya, perbaikannya gimana."

Berdasarkan hasil wawancara tersebut dapat disimpulkan, bahwa walaupun tidak ada aturan tertulis yang menyatakan PSN mengalahkan LP2B, pada praktik di lapangan keberadaan LP2B lemah apabila dihadapkan dengan proyek pembangunan infrastruktur yang merupakan PSN. Hal ini dikarenakan persepsi dan kebijakan pimpinan untuk cenderung mengutamakan pembangunan infrastruktur dengan berdasar pada Undang Undang Pengadaan Tanah untuk Pembangunan bagi Kepentingan Umum (UUPTPKU).

\section{Proses Pelaksanaan Pengadaan Tanah Pada LP2B}

Salah satu, pelaksanaan pengadaan tanah LP2B di Kabupaten Boyolali adalah pembangunan jalur kereta api Bandara Adi Soemarmo. Pembangunan jalur kereta api dimaksudkan untuk mengakomodasi dan mengantisipasi pergerakan lalu lintas penumpang yang terjadi di Bandara Adi Soemarmo melalui pembangunan jalur kereta api sebagai moda alternatif transportasi massal penumpang pesawat menuju bandara, yang bersinergi dengan rel ganda kereta api jalur Solo-Semarang. PT.KAI merencanakan pembangunan Jalur Kereta Api Akses Bandara Adi Soemarmo Lintas Solo Balapan - Adi Soemarmo sepanjang $\pm 13,5 \mathrm{~km}$ (KM 107+914 - KM 104+414) dan (KM o+ooo - KM 10+ooo) dengan kebutuhan lahan kurang lebih 12,94 Ha. Jalur tersebut ditetapkan berdasarkan Kepmen PU No.KP 406 Tahun 2017 tentang Penetapan Trase Jalur Kereta Api Umum Nasional Lintas Stasiun Solo Balapan-Stasiun Bandar Udara Adi Soemarmo tanggal 6 April 2017. Dengan adanya kepmen ini, pergeseran letak dimungkinkan, namun tidak bisa jauh dari titik yang ditetapkan, sehingga mau tidak mau jalur kereta api berada di tempat tersebut. Kenyataannya sebagian lokasi yang dimohon masuk pada kawasan LP2B. Dengan terbitnya surat ini menandakan bahwa dalam pengadaan tanah tidak memandang LP2 $\mathrm{B}$ atau bukan.

Berdasarkan pada UUPTPKU dan peraturan turunannya, proses tahapan kegiatan pengadaan tanah terdiri dari 4 tahap, yaitu perencanaan, persiapan, pelaksanaan dan penyerahan hasil.

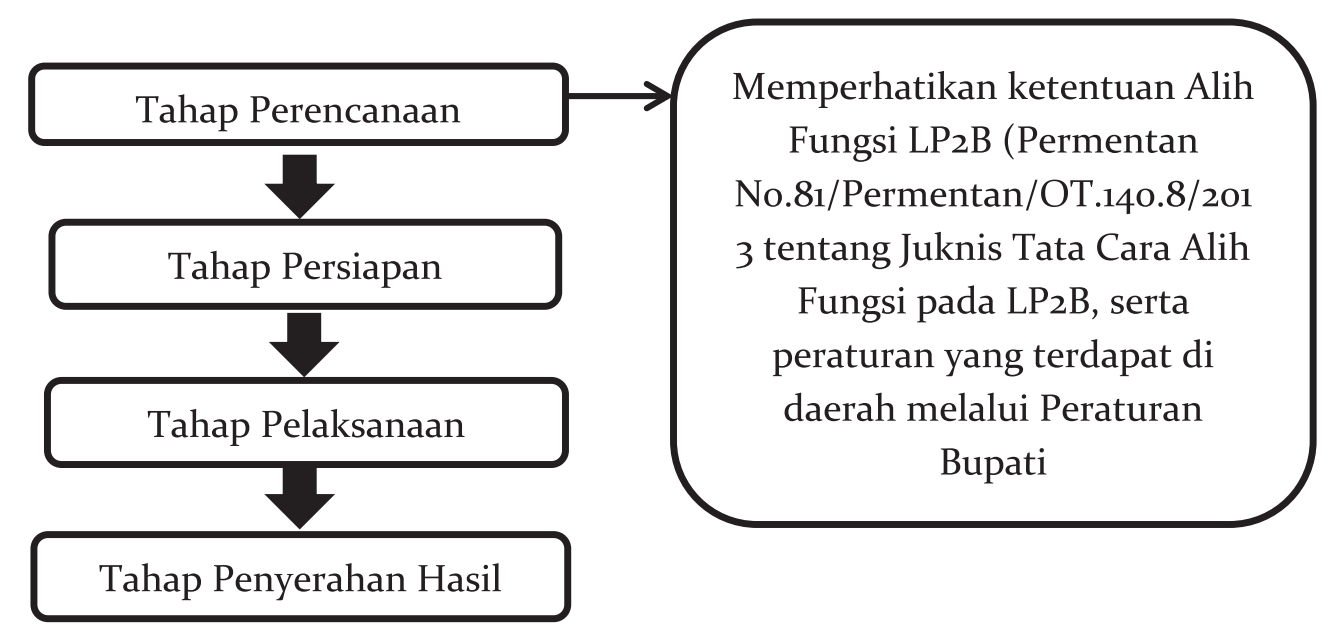

Gambar 3. Tahapan Kegiatan Pengadaan Tanah Sumber: UUPTKU, 2012

a. Tahap Perencanaan.

Pada tahap ini BTPKI membuat dokumen perencanaan untuk diajukan ke gubernur. Sebelum pembuatan dokumen perencanaan, maka instansi yang memerlukan tanah harus membuat 
surat permohonan informasi tata ruang, dalam hal ini terbit surat Sekda Pemkab Boyolali No.050/04113/12/2016 tanggal 18 Oktober 2016, yang menyatakan bahwa lokasi yang dimohon dapat dimanfaatkan untuk pembangunan jalur kereta api. Surat tersebut menyatakan bahwa lokasi pengadaan tanah berada pada kawasan budidaya berdasarkan RTRW Kabupaten Boyolali. Kenyataannya sebagian lokasi yang dimohon masuk pada kawasan LP2B. Dengan terbitnya surat ini menandakan bahwa dalam pengadaan tanah tidak memandang $\mathrm{LP}_{2} \mathrm{~B}$ atau bukan.

Rencana pembangunan jalur kereta ini telah sesuai dengan tata ruang, baik RTRWN, RTRW Provinsi dan RTRW Kabupaten, namun tidak sesuai apabila dihadapkan dengan Perda LP2B, karena rencana pembangunan melalui lahan yang telah ditetapkan menjadi LP2B. Dalam RTRWN, Pasal 20 PP No.26 Tahun 2008 menguraikan tentang jaringan jalur kereta api yang terdiri dari jaringan jalur kereta api umum dan khusus. Jalur kereta api Bandara Adi Soemarmo- Stasiun Solo Balapan termasuk didalam Peraturan Menteri Perhubungan No.43 Tahun 2011 tentang Rencana Induk Perkeratapian Nasional. Kesesuaian terhadap RTRW Provinsi Jawa Tengah, ditunjukkan pada Pasal 24 ayat (2) huruf (a), yang menunjukkan bahwa Bandar Udara Adi Soemarmo yang merupakan bandar udara pengumpul menjadi proyek pengembangan jaringan prasarana bandara. Selanjutnya, dalam RTRW Kabupaten Boyolali tahun 2011-2031 telah direncanakan sistem prasarana utama, dalam Pasal 19 ayat (2) huruf (a) melalui "pengembangan intermoda terminal dengan akses ke Bandar Udara Internasional Adi Soemarmo Boyolali”.

Dalam dokumen perencanaan memuat gambaran umum mengenai wilayah dan status tanah rencana lokasi pembangunan jalur kereta api. Dalam gambaran umum tersebut disebutkan bahwa rencana pembangunan melintasi Kecamatan Ngemplak dengan 7 (tujuh) desa/kelurahan, antara lain: Sawahan, Pandeyan, Kismoyoso, Donohudan, Sindon, Dibal dan Ngresep. Dalam dokumen perencanaan data jumlah bidang tanah yang terdampak adalah 563 bidang tanah. Berdasarkan data nominatif tersebut, diperoleh rincian luasan penggunaan lahan bidang tanah terdampak di Kabupaten Boyolali, seperti terlihat pada Tabel 2.

Tabel.2. Rencana Kebutuhan Tanah Pembangunan Jalur Kereta Api Akses Bandara Adi Soemarmo- Solo Balapan

\begin{tabular}{llll}
\hline Kecamatan & Penggunaan Tanah & Luas Tanah $\left(\mathbf{m}^{2}\right)$ & \multicolumn{1}{c}{ Analisis Pola Ruang RTRW } \\
\hline Ngemplak & Tanah Sawah & $97.436,70$ & $\begin{array}{l}\text { Kawasan budidaya dengan peruntukan kawasan } \\
\text { pertanian lahan basah, }\end{array}$ \\
& $\begin{array}{l}\text { Tanah Darat } \\
\text { (pekarangan, tegalan) }\end{array}$ & $21.338,50$ & $\begin{array}{l}\text { Kawasan budidaya dengan Peruntukan kawasan } \\
\text { transportasi udara, dan kawasan permukiman pedesaan }\end{array}$ \\
& & $118.775,2$ & \\
\hline
\end{tabular}

Sumber: Balai Teknik Perkeretapian Kelas I, 2020.

Dalam penelitian ini rencana pembangunan untuk jalur kereta api mengenai lahan pertanian seluas 97.436 meter persegi berada di Kecamatan Ngemplak. Berdasarkan pola ruangnya Kecamatan Ngemplak, termasuk dalam kawasan budidaya dengan peruntukan pertanian lahan basah, kawasan transportasi udara dan kawasan permukiman pedesaan. Dengan adanya kawasan budidaya maka kawasan tersebut dapat dikembangkan sesuai peruntukkannya. Namun demikian dalam kawasan tersebut juga terdapat kawasan PLP2B yang dilarang untuk dialihfungsikan. Berdasarkan Perda 17/2016, Kecamatan Ngemplak mempunyai lahan LP2B seluas 1.283.104 meter persegi, sehingga terjadinya alih fungsi pada LP2B. Gambar 4 dibawah ini menunjukkan hasil identifikasi rencana pembangunan jalur kereta api pada kawasan LP2B. 


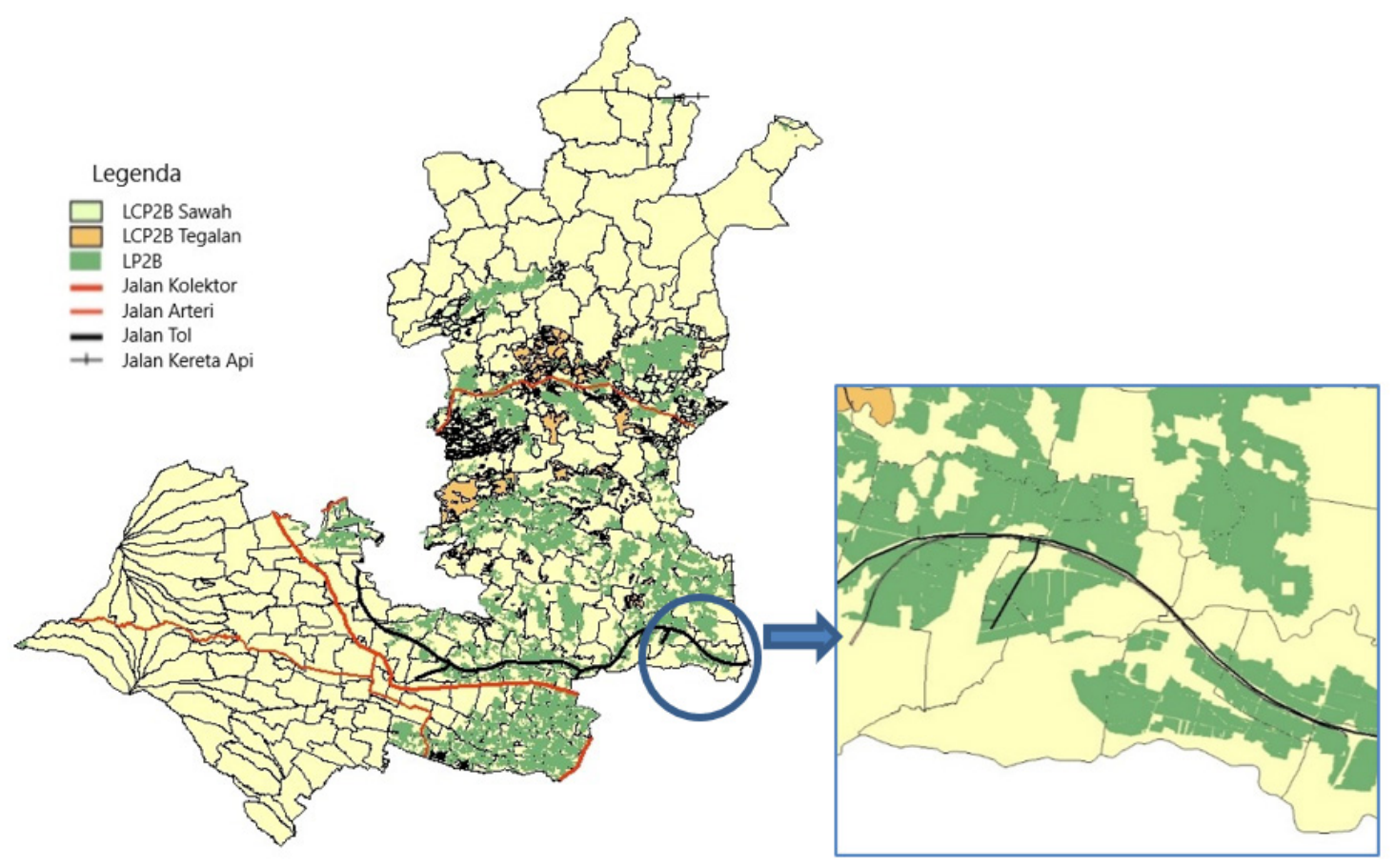

Gambar 4. Peta Identifikasi Bidang Tanah Pembangunan Jalur Kereta Api Pada LP2B. Sumber: Hasil Analisis, 2021.

Berdasarkan pada peta diatas terlihat bahwa pembangunan jalur kereta api mengenai lahan LP2B dan non LP2B. Luas pembangunan yang mengenai bidang tanah LP2B di Kecamatan Ngempak seluas 43.820 meter persegiatau 3,4 \% dari luas LP2B di Kecamatan Ngemplak. LP2B yang dimaksud berupa sawah irigasi teknis dengan pola tanamnya lebih dari 2 kali panen dan mempunyai produktifitas lebih dari 4,5 ton per tahun.

Dalam ketentuan Pasal 44 ayat (2) disebutkan bahwa "alih fungsi untuk kepentingan umum dilakukan sesuai ketentuan peraturan perundang-undangan". Ketentuan peraturan perUU yang dimaksud antara lain: Permentan No.81/Permentan/OT.140.8/2013 tentang Juknis Tata Cara Alih Fungsi pada LP2B, serta peraturan yang terdapat di daerah melalui Peraturan Bupati. Namun Peraturan Bupati tentang alih fungsi LP2B sampai saat ini belum ditetapkan.

Alih fungsi LP2B dalam rangka pengadaan tanah untuk pembangunan infrastruktur diberikan izinnya setelah instansi yang memerlukan lahan membuat surat permohonan kepada bupati /walikota atau gubernur. Alih fungsi $\mathrm{LP}_{2} \mathrm{~B}$ dapat dilakukan apabila memenuhi persyaratan antara lain memiliki kajian kelayakan strategis, rencana alih fungsi lahan, pembebasan hak milik atas tanah dan penyediaan lahan penganti. Berdasarkan Permentan No.81/Permentan/OT.140.8/2013, dalam menyusun Kajian kelayakan strategis harus meliputi:

"Luas dan lokasi lahan yang akan dialihkan, potensi kehilangan hasil pangan akibat konversi, nilai resiko akibat konversi, dampak pada penurunan penyerapan tenaga kerja pertanian, dan perkiraan perubahan pada sosio kultural masyarakat (kekerabatan, pemukiman dll)".

Berdasarkan hasil penelitian, dalam kegiatan perencanaan pengadaan jalur kereta api tidak melalui tahap musyawarah dengan dinas pertanian. Akibatnya dinas pertanian tidak dapat ikut berperan dalam memberikan pendapat dan saran terkait pelaksanaan pengadaan tanah serta tidak dapat mengontrol pemenuhan persyaratan dalam kegiatan alih fungsi LP2B. Hal ini dapat terlihat dalam dokumen kajian kelayakan strategis tidak berisi dampak dan akibat dari konversi lahan pertanian, tetapi lebih ke analisis dampak lingkungan serta persetujuan prinsip dari rencana kegiatan pengadaan tanah. Rencana alih 
fungsi tanah tidak memuat lahan pengganti dan pemanfaatan lahan penggantinya, hanya pelaksanaan pra-konstruksi dan konstruksi. Penyediaan lahan dilakukan dengan penertiban lahan terhadap aset PT.KAI dan pembebasan lahan. Selain itu, ketentuan lahan pengganti juga tidak terpenuhi.

Dengan teralihfungsikannya LP2B untuk pembangunan jalur kereta apiakses Bandara Adi SoemarmoStasiun Solo Balapan, maka diperlukan lahan pengganti. Ketersediaan lahan pengganti ini berdasarkan pada Permentan No. 81/Permentan/OT.140.8/2013 bahwa alih fungsi dapat dilakukan setelah lahan pengganti yang diminta oleh pemilik lahan telah terpenuhi sesuai dengan peraturan. Berdasarkan hasil penelitian, lahan pengganti tidak disediakan sebelum kegiatan alih fungsi dilaksanakan. Dalam implementasinya, lahan pengganti disediakan oleh Pemerintah dalam hal ini dinas Pertanian bekerja sama dengan $\mathrm{BPN}, \mathrm{BP}_{3} \mathrm{D}$ dan dinas $\mathrm{PU}$.

Implementasi pelaksanaan alih fungsi $\mathrm{LP}_{2} \mathrm{~B}$ dalam pengadaan tanah jalur kereta api Bandara Adi Soemarmo-Stasiun Solo Balapan tidak sesuai dengan ketentuan. Dari tahap perencanaan ini sudah terlihat betapa lemahnya keberadaan $\mathrm{LP}_{2} \mathrm{~B}$ apabila berhadapan dengan pelaksanaan pembangunan infrastruktur. Aturan yang telah dibuat dengan jelas dan rigid dalam melindungi keberadaan $\mathrm{LP}_{2} \mathrm{~B}$, namun adanya kekuatan dari pembuat kebijakan dalam mempersepsikan kebijakan membuat alih fungsi untuk pembangunan infrastruktur tidak dapat terelakkan lagi. Hal ini terlihat dari ketentuan alih fungsi yang belum terpenuhi, namun dengan pembangunan infrastruktur berupa jalur kereta api Bandara tetap terlaksana.

\section{b. Tahap Persiapan}

Pada tahap ini, instansi yang memerlukan tanah mengajukan surat permohonan penetapan lokasi kepada Gubernur Jawa Tengah. Kebijakan pemerintah dalam kegiatan pengadaan tanah ini ditandai dengan terbitnya surat keputusan penetapan lokasi yang ditetapkan oleh gubernur yaitu SK No.590/80 Tahun 2017 tentang persetujuan penetapan lokasi pengadaan tanah bagi pembangunan jalur kereta Bandara Adi Soemarmo lintas Solo Balapan- Bandara Adi Somarmo di Kabupaten Boyolali dan Kota Surakarta pada tanggal 12 Oktober 2017.

Berdasarkan pada diktum kedua huruf (c) SK Penlok menunjukkan bahwa penyelesaian terhadap tanah dan/atau bangunan melalui ketentuan peraturan perundang-undangan. Ketentuan yang dimaksud adalah mengenai ketentuan pembayaran ganti rugi sesuai dengan UUPTPKU. Dari sudut pandang $\mathrm{LP} 2 \mathrm{~B}$, apabila tanah pertanian merupakan $\mathrm{LP}_{2} \mathrm{~B}$ maka hal ini sangat melemahkan keberadaan $\mathrm{LP}_{2} \mathrm{~B}$, karena pemilik lahan menerima bentuk ganti rugi dalam bentuk uang (sesuai kesepakatan), sehingga akibatnya pemilik lahan LP2B yang dilepaskan tidak serta merta menjadi pemilik pada lahan pengganti untuk $\mathrm{LP}_{2} \mathrm{~B}$.

Definisi penetapan lokasi berdasarkan Perpres RI No.148 Tahun 2015 tentang perubahan keempat atas perpres No.71 Tahun 2012 tentang penyelenggaraan pengadaan tanah bagi pembangunan untuk kepentingan umum, yaitu:

"Penetapan Lokasi adalah penetapan atas lokasi pembangunan untuk kepentingan umum yang ditetapkan dengan keputusan gubernur, yang dipergunakan sebagai izin untuk Pengadaan Tanah, perubahan penggunaan tanah, dan peralihan hak atas tanah dalam Pengadaan Tanah bagi pembangunan untuk kepentingan umum."

Dengan berdasarkan pada peraturan tersebut bahwa dengan SK Penlok merupakan izin dari pelaksanaan pengadaan tanah. Selain itu, informasi mengenai pelaksanaan pengadaan tanah diperoleh melalui wawancara. Pejabat kantor pertanahan Kabupaten Boyolali (2020) mengatakan bahwa "setelah ada penetapan lokasi dari gubernur dan surat permohonan instansi ke Kakanwil, Kakanwil membuat pelimpahan kewenangan kepada kakantah sebagai ketua tim pengadaan tanah, baru kemudian kepala kantor pertanahan membentuk Tim untuk melakukan kegiatan inventarisasi data fisik, yuridis". Dengan 
demikian setelah adanya SK Penlok tersebut menandakan bahwa kegiatan pengadaan tanah segera dimulai. Pejabat Dinas Pertanian (2020) mengatakan bahwa "setelah adanya penetapan lokasi dari Gubernur, maka kita tidak bisa berbuat apa-apa, karena kita harus selalu mendukung segala program Pemerintah". Informasi dari dinas Pertanian menyatakan bahwa dengan adanya penetapan lokasi, maka pelaksanaan pengadaan tanah segera dilaksanakan. Dengan demikian berdasarkan peraturan dan implementasi di lapangan bahwa kunci dari pelaksanaan pengadaan tanah adalah adanya penetapan lokasi. Penetapan lokasi dilakukan setelah melalui beberapa kajian terutama kesesuaian dengan tata ruang baik pada tingkat daerah kabupaten/kota. Dengan adanya Penetapan lokasi maka baik lahan sawah LP2B atau bukan akan teralih fungsi. Hal ini menunjukkan bahwa LP2B mempunyai kedudukan yang lebih lemah dibandingkan dengan kepentingan pembangunan infrastruktur.

Dengan demikian jelas bahwa kebijakan pengadaan tanah lebih menduduki tempat yang superior, karena banyaknya kebijakan yang pro dengan pembangunan infrastruktur sehingga dapat mengkonversi semua tanah termasuk didalamnya tanah yang dilindungi kelestariannya seperti $\mathrm{LP}_{2} \mathrm{~B}$. Dengan kata lain, kepentingan umum untuk pelestarian seperti LP2B selalu kalah dengan kepentingan umum untuk pembangunan infrastruktur.

c. Tahap Pelaksanaan

Pada tahap ini dilaksanakan inventarisasi dan identifikasi dilakukan oleh Satgas Adan Satgas B. Satgas A bertugas terkait data fisik penguasaan, kepemilikan, penggunaan dan pemanfaatan tanah. Satgas B bertugas terkait data yuridis Pihak yang berhak dan objek pengadaan tanah. Tabel 3 merupakan rekapitulasi hasil identifikasi dan inventarisasi penguasaan, pemilikan, dan pemanfaatan tanah.

Tabel.3. Rekapitulasi Hasil Identifikasi dan Inventarisasi Penguasaan, Pemilikan, dan Pemanfaatan Tanah Pengadaan Tanah Pembangunan Jalur Rel Kereta Api Akses Bandara Adi Soemarmo-Stasiun Solo Balapan

\begin{tabular}{|c|c|c|c|c|c|c|c|c|}
\hline Desa & $\begin{array}{c}\text { Tanggal } \\
\text { inventarisasi }\end{array}$ & Status Tanah & $\begin{array}{c}\text { Jumlah Bidang } \\
\text { Pekarangan/ } \\
\text { tegalan }\end{array}$ & $\begin{array}{l}\text { Luas } \\
(\mathbf{M} 2)\end{array}$ & $\begin{array}{l}\text { Jumlah } \\
\text { Bidang } \\
\text { Sawah }\end{array}$ & $\begin{array}{l}\text { Luas } \\
(\mathbf{M 2})\end{array}$ & $\begin{array}{c}\text { Total } \\
\text { Bidang }\end{array}$ & $\begin{array}{l}\text { Luas Total } \\
\text { (M2) }\end{array}$ \\
\hline \multirow[t]{3}{*}{ Ngresep } & $19 / 03 / 2018$ & Masyarakat & 9 & 1453 & 15 & 4057 & 24 & 5510 \\
\hline & & $\begin{array}{l}\text { Instansi } \\
\text { Pemerintah }\end{array}$ & 3 & 12831 & o & o & 3 & 12831 \\
\hline & & TKD & o & o & 2 & 624 & 2 & 624 \\
\hline Sindon & $04 / 05 / 2018$ & Masyarakat & 4 & 200 & 15 & 2779 & 19 & 2979 \\
\hline \multirow[t]{2}{*}{ Dibal } & $19 / 05 / 2018$ & Masyarakat & 13 & 1102 & 82 & 16009 & 95 & 17111 \\
\hline & & TKD & 1 & 825 & 2 & 196 & 3 & 1021 \\
\hline \multirow[t]{2}{*}{ Kismoyoso } & $24 / 09 / 2018$ & Masyarakat & 11 & 2806 & o & o & 11 & 2806 \\
\hline & & $\begin{array}{l}\text { Tanah Kas } \\
\text { Desa }\end{array}$ & o & o & 1 & 387 & 1 & 387 \\
\hline Donohudan & $23 / 07 / 2018$ & Masyarakat & 14 & 2445 & 20 & 1658 & 34 & 4103 \\
\hline \multirow[t]{2}{*}{ Pandeyan } & $21 / 05 / 2018$ & Masyarakat & o & o & 93 & 6580 & 93 & 6580 \\
\hline & & TKD & o & o & 6 & 462 & 6 & 462 \\
\hline \multirow[t]{2}{*}{ Sawahan } & $07 / 09 / 2018$ & Masyarakat & o & o & 40 & 25705 & 40 & 25705 \\
\hline & & TKD & o & o & 6 & 3388 & 6 & 3388 \\
\hline Jumlah & & & 55 & 21662 & 282 & 61845 & 337 & 83507 \\
\hline
\end{tabular}

Sumber: Kantor Pertanahan Kabupaten Boyolali, 2020.

Berdasarkan pada tabel hasil inventarisasi dan identifikasi diatas, menunjukkan jumlah bidang yang digunakan untuk pelepasan hak sejumlah 337 bidang dengan luas total 83.507 meter persegi yang terdiri dari lahan sawah seluas 61.845 meter persegi dan lahan pekarangan/tegalan/perumahan seluas 21.662 meter persegi. Berdasarkan pada hasil inventarisasi dan identifikasi bidang tanah 
kemudian bidang tanah tersebut dilakukan penilaian. Penilaian dilakukan oleh KJPP Sih Wiryadi dan rekan berdasarkan BA No.4265.1/BA-33.09/XII/2018. Berdasarkan Pasal 33 UUPTKU, penilaian dilakukan terhadap "tanah, ruang atas tanah dan bawah tanah, bangunan, tanaman, benda yang berkaitan dengan tanah dan kerugian lain yang dapat dinilai (solatium/kerugian emosional, BPHTB, PPAT, kompensasi masa tunggu)".

Setelah dilakukan penilaian, kemudian dilakukan musyawarah penetapan bentuk ganti kerugian. Pada musyawarah dihadiri oleh BPTK I Wilayah Jawa Bagian Tengah, Kadin PU Kab.Boyolali, Kadin Pertanian Kab. Boyolali, Kepala PN Kab. Boyolali, Kepala Kejaksaan, Camat Ngemplak, Kepala Desa, Komandan Rayon Militer Kecamatan Ngemplak, Kepala Kepolsek Ngemplak, Babinsan dan BRI. Berdasarkan hasil musyawarah diperoleh kesepakatan bahwa bentuk ganti rugi adalah uang. Berdasarkan data Kantor Pertanahan Kabupaten Boyolali per Oktober 2020, pemberian ganti kerugian sudah dilakukan terhadap 329 bidang konsinyasi masih tersisa 8 (delapan) bidang tanah. Konsinyasi dilakukan karena masyarakat ada yang menolak bentuk dan/atau besar ganti kerugian serta pihak yang berhak tidak hadir dan tidak diketahui keberadaannya. Dengan telah diterimanya ganti kerugian pada yang berhak maka secara hukum juga terjadi pelepasan hak atas tanah dari pemegang hak lama kepada pemegang hak baru, sehingga hak dan kewajiban pemegang hak juga beralih ke pemegang hak yang baru, yaitu BPTKI Wilayah Jawa bagian Tengah.

Pada tahap pelaksanaan pengadaan tanah telah berjalan dengan lancar dan sesuai dengan ketentuan dalam UUPTPKU dan perubahannya. Namun demikian dijumpai kendala terutama dalam pelaksanaan pengadaan tanah, antara lain: keberadaan pemilik tanah yang tidak tinggal di Kab. Boyolali maupun tidak diketahui keberadaannya sehingga uang ganti rugi harus melalui konsinyasi, pemilik tanah tidak bisa menunjukkan batas bidang tanahnya, sehingga terjadi selisih luas, serta masih adanya sengketa waris. (hasil wawancara dengan pejabat Kantor Pertanahan Kab. Boyolali, 2020).

\section{d. Tahap Penyerahan Hasil}

Hasil kegiatan pengadaan tanah adalah dokumen pengadaan tanah yang diberikan kepada instansi yang memerlukan tanah yang digunakan untuk permohonan sertipikat hak atas tanah. Biaya penerbitan sertipikat baik tanah sisa dan tanah hasil pengadaan tanah ditanggung oleh instansi yang memerlukan tanah.

\section{Revisi Kebijakan PLP2B}

Weible \& Heikkila (2017) menjelaskan dalam kerangka konflik kebijakan antara penetapan kebijakan, episode konflik kebijakan dan umpan balik merupakan sebuah siklus yang saling mempengaruhi dan berlanjut. Dalam penelitian ini, konflik kebijakan $\mathrm{PLP}_{2} \mathrm{~B}$ dalam pelaksanaan pengadaan tanah merupakan konflik kebijakan dimana pemerintah bersedia berkompromi agar tercipta keharmonisan dalam kebijakan penataan ruang. Revisi dianggap sebagai tahap akhir / umpan balik dari suatu proses implementasi kebijakan, tetapi menjadi awal implementasi yang baru, sehingga terlihat sebagai siklus.

Revisi dilakukan karena dalam kebijakan PLP2B diatur syarat dilaksanakannya alih fungsi dan adanya ketentuan mengenai lahan pengganti. Alih fungsi mengakibatkan perubahan data spasial dalam peta $\mathrm{PLP}_{2} \mathrm{~B}$ di Kabupaten Boyolali, karena lahan yang semula $\mathrm{LP}_{2} \mathrm{~B}$ menjadi tidak LP2B. demikian juga dengan adanya ketersediaan lahan pengganti, mengakibatkan perubahan data spasial dalam peta PLP2B. Penetapan lahan pengganti $\mathrm{LP}_{2} \mathrm{~B}$ menjadi kunci dari pelaksanaan revisi kebijakan yang merupakan output dalam kerangka konflik kebijakan untuk dapat mempertahankan luasan dari kebijakan PLP2B di Kabupaten Boyolali.

Berdasarkan hasil wawancara dengan pejabat Dinas Pertanian Kabupaten Boyolali diperoleh informasi bahwa revisi kebijakan PLP2B pada saat ini belum ditetapkan, tetapi proses mencari lahan pengganti sudah mulai dilakukan. Revisi tersebut meliputi pencarian lahan pengganti untuk menganti 
LP2B yang teralih fungsi karena pembangunan jalur kereta api, namun juga mengevaluasi layak tidaknya $\mathrm{LP}_{2} \mathrm{~B}$ yang telah ada. Evaluasi perlu dilaksanakan karena dalam implementasi kebijakan, terutama pembangunan infrastruktur membawa dampak terutama terkait dengan penurunan produktifitas lahan LP2B. Hasil nyata dari rencana revisi tersebut adalah telah dibuat peta rencana PLP2B tahun 2021. Gambar 5 di bawah ini merupakan Peta Rencana Revisi Perda 17/2016.

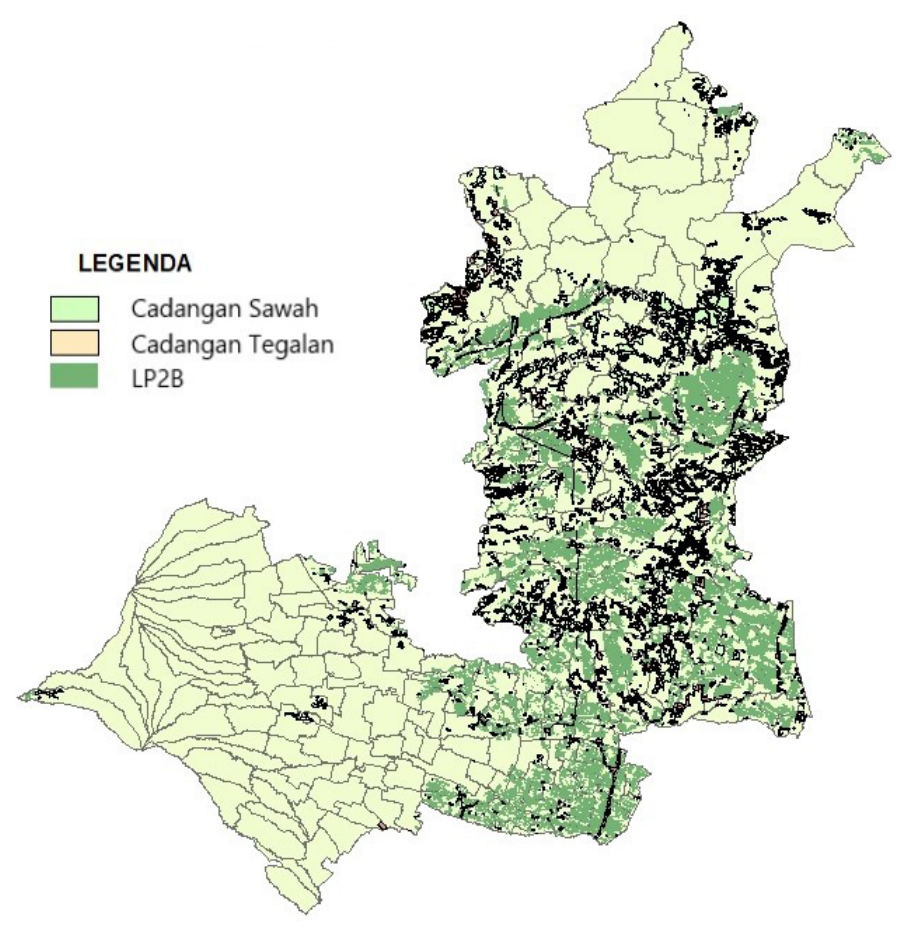

Gambar 5. Peta Rencana Revisi Perda PLP2B Tahun 2016

Sumber: Kantor Pertanahan Kabupaten Boyolali, 2020

Revisi kebijakan akan dipelopori oleh Dinas Pertanian, Dinas Pekerjaan Umum dan Penataan Ruang, Badan Perencanaan Penelitian dan Pengembangan Daerah (BP3D), serta Kantor Pertanahan Kabupaten Boyolali. Pada tahap mencari lahan pengganti dilakukan dengan intepretasi citra yang memenuhi syarat untuk dapat ditetapkan menjadi $\mathrm{LP}_{2} \mathrm{~B}$. Strateginya adalah menetapkan $\mathrm{LP}_{2} \mathrm{~B}$ yang berasal dari $\mathrm{LCP}_{2} \mathrm{~B}$ maupun lahan baru, menetapkan $\mathrm{LCP}_{2} \mathrm{~B}$ dari $\mathrm{LP}_{2} \mathrm{~B}$ yang sudah tidak memenuhi kriteria menjadi $\mathrm{LP}_{2} \mathrm{~B}$ dan berasal dari lahan baru. Pemerintah berupaya hanya memenuhi luasan yang sama dengan luas $\mathrm{LP}_{2} \mathrm{~B}$ yang teralih fungsi. Hal ini dilakukan karena pemerintah kesulitan untuk menetapkan $\mathrm{LP}_{2} \mathrm{~B}$ sesuai dengan kriteria UU. Pada saat ini Pemerintah telah menetapkan rencana PLP2B namun belum ditetapkan dalam Perda Revisi. Rencananya pada tahun 2021 revisi Perda PLP2B akan mulai diajukan ke bagian hukum Sekretariat Daerah Kabupaten Boyolali.

\section{Interpretasi: Konflik Kebijakan}

Kebijakan pengadaan tanah untuk kepentingan umum yang terjadi pada lahan LP2B di Kabupaten Boyolali merupakan contoh fenomena konflik kebijakan penataan ruang yang terjadi di Indonesia. Definisi konflik di sini adalah suatu bentuk pertentangan kebijakan dalam mencapai tujuannya. Konflik kebijakan muncul ketika kebijakan saling berpengaruh dan menjadikan ancaman bagi kebijakan yang lain. Pengungkapan fenomena konflik seperti ini perlu diungkap dalam konteks studi politik dan kebijakan publik untuk menghasilkan efek umpan balik pada pengaturan kebijakan (Weible \& Heikkila, 2017).

Dalam penelitian ini, kebijakan pengadaan tanah menjadi ancaman kebijakan PLP2B. Pemerintah yang telah berkomitmen untuk melestarikan lahan pertaniannya dengan menetapkan kawasan $\mathrm{LP}_{2} \mathrm{~B}$ 
melalui Perda LP2B, namun ketika dihadapkan kebijakan pengadaan tanah berupa pembangunan jalur kereta api Bandara Adi Soemarmo, komitmen tercabut menjadi tindakan konversi LP2B. Indikasi adanya ambiguitas dan inkonsistensi kebijakan. Nugrahani (2019) mengungkapkan bahwa ambiguitas terhadap isi kebijakan merupakan penyebab dinamika implementasi kebijakan publik. Isi kebijakan yang ambigu antara mendukung atau bertentangan inilah yang nantinya berkontribusi dalam menciptakan konflik kebijakan yang ada.

Di Kabupaten Boyolali, kebijakan PLP2B mempunyai tujuan melestarikan lahan pertanian pangan, konsekuensinya lahan tersebut tidak dapat dialihfungsikan. Namun dalam Pasal 44 UUPLP2B menyatakan bahwa LP2B dapat dialihfungsikan untuk kepentingan umum dengan syarat dan ketentuan yang berlaku antara lain: kajian kelayakan strategis, rencana alih fungsi, pembebasan HAT dan lahan pengganti. Hal ini merupakan ambiguitas dari kebijakan PLP2B, karena dalam satu kebijakan terdapat pertentangan. Selain itu, adanya UUPTPKU beserta turunannya semakin memantapkan pelaksanaan alih fungsi tanah untuk kepentingan umum dalam hal ini pembangunan infrastruktur. Pembuat kebijakan dalam memutuskan kebijakan cenderung berpedoman pada UUPTPKU dan turunannya. Disamping itu, dukungan Presiden melalui percepatan PSN dalam mewujudkan visi dan misi Presiden terutama dalam pembangungan infrastruktur juga ditetapkan. Hal ini membuat pelaku kebijakan semakin mantap dalam melaksanakan kebijakan pengadaan tanah untuk pembangunan infrastruktur daripada melestarikan lahan pertanian. Berdasarkan hasil penelitian, diperoleh informasi bahwa dalam melakukan alih fungsi untuk kegiatan pengadaan tanah jalur kereta api Bandara Adi SoemarmoStasiun Solo Balapan, ketentuan alih fungsi tidak berjalan semestinya. Hal ini terlihat dalam dokumen perencanaan yang tidak ditemukan pemenuhan persyaratan dalam alih fungsi LP2B. Dengan demikian tampak bahwa pemimpin di daerah mempunyai kecenderungan untuk mementingkan kepentingan pembangunan infrastruktur daripada kepentingan umum untuk pelestarian seperti $\mathrm{LP}_{2} \mathrm{~B}$. Konflik kebijakan muncul karena adanya dukungan dari pemimpin di daerah.

Weible \& Heikkila (2017) mengungkapkan bahwa atribut yang penting dalam konflik adalah intensitasnya. Keberadaan relatif tidaknya karakteristik kognitif diantara aktor kebijakan menentukan tingkat konflik. Karakteristik kognitif dalam kerangka konflik kebijakan terdiri atas perbedaan kedudukan, tingkat ancaman dan kemauan kompromi. Berdasarkan intensitas konflik Weible \& Heikkila (2017), maka kebijakan pengadaan tanah dan kebijakan PLP2B mempunyai intensitas sedang. Intensitas kebijakan dapat dilihat pada gambar dibawah ini:

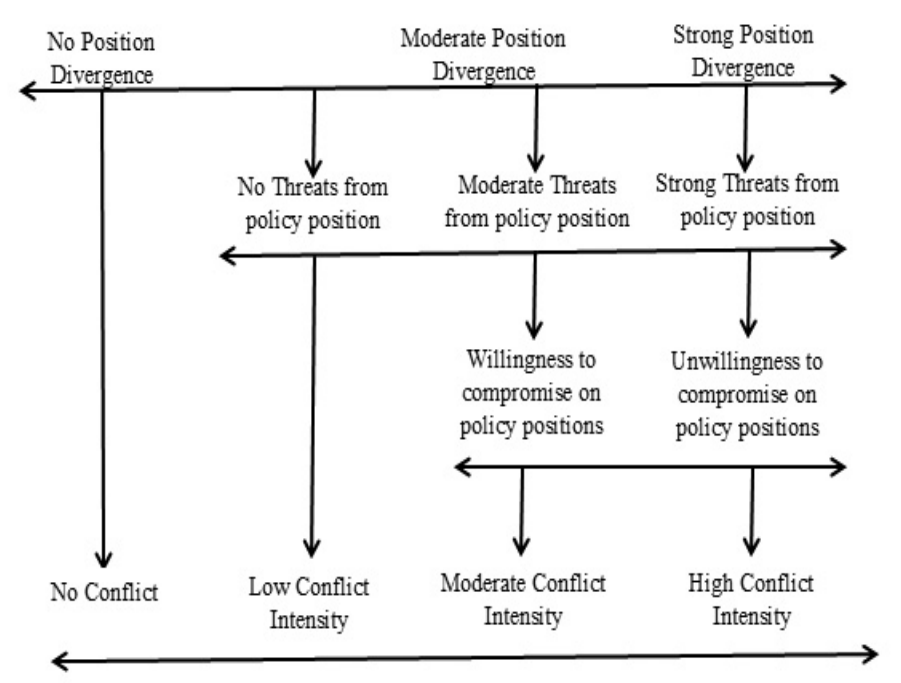

Gambar 6. intensitas spektrum Konflik Kebijakan di Kabupaten Boyolali Sumber : Weible \& Heikkila, 2017. 
Pengadaan tanah merupakan hal yang khusus, karena merupakan upaya pemerintah untuk mencapai tujuan negara melalui pembangunan infrastruktur, selain itu pengadaan tanah merupakan pengaturan lebih lanjut dari tanah untuk kepentingan umum. Prinsip dalam penegakan hukum terdapat "lex specialis derogate legi generali" yang artinya hukum yang bersifat khusus mengalahkan yang sifatnya umum. Dalam hal ini UUPTPKU tersebut bersifat khusus sehingga dalam implementasinya lebih diutamakan, selain itu dorongan dari aktor yaitu presiden dengan memasukkan sebagian proyek pembangunan dalam PSN menjadikan kebijakan PTPKU lebih diutamakan.

Pembangunan infrastruktur tersebut dimaksudkan untuk mewujudkan konektifitas yang baik, sehingga pertumbuhan ekonomi dapat tercapai. Dengan adanya pertumbuhan ekonomi yang baik menciptakan keadilan dan kesejahteraan masyarakat. Dengan adanya alih fungsi pada LP2B untuk kepentingan umum, menunjukkan bahwa kepentingan umum untuk pelestarian seperti LP2B selalu kalah dengan kepentingan umum untuk pertumbuhan dalam hal ini pembangunan infrastruktur.

Ancaman dari kedudukan kebijakan PLP2B adalah kebijakan pengadaan tanah. Ketika lahan pertanian dilindungi keberadaannnya dan dijamin keberlanjutannya, namun berubah penggunaannya menjadi lahan terbangun untuk alasan kepentingan umum. Dengan demikian, kebijakan PLP2B berada pada posisi yang lemah apabila dibandingkan dengan kebijakan PTPKU. Kemauan berkompromi dari kebijakan itu adalah ketentuan Pasal 44 UUPLP2B. Pada Pasal tersebut, diatur syarat dilaksanakannya alih fungsi dan adanya ketentuan mengenai lahan pengganti. Yang selanjutnya diintegrasikan dalam kebijakan tata ruang daerah kabupaten, sehingga tetap tercipta keseimbangan dalam implementasi kebijakan.

\section{Kesimpulan}

Pelaksanaan pengadaan tanah dilakukan melalui 4 (empat) tahap, tetapi yang menentukan alih fungsi terjadi atau tidak adalah pada tahap perencanaan dan persiapan dari kegiatan pengadaan tanah. Pada tahap perencanaan, pelaksanaan alih fungsi $\mathrm{LP}_{2} \mathrm{~B}$ dalam pengadaan tanah jalur kereta api Bandara Adi Soemarmo-Stasiun Solo Balapan di Kabupaten Boyolali belum sesuai dengan ketentuan peraturan perundang-undangan. Kemudian, pada tahap persiapan dengan adanya keputusan gubernur tentang penetapan lokasi menunjukkan betapa lemahnya keberadaan LP2 $\mathrm{B}$ apabila berhadapan dengan pelaksanaan pembangunan infrastruktur. Kebijakan pengadaan tanah lebih menduduki tempat yang superior, karena banyaknya kebijakan yang pro dengan pembangunan infrastruktur sehingga dapat mengkonversi semua tanah termasuk didalamnya tanah yang dilindungi kelestariannya seperti LP2B. Kebijakan yang pro pembangunan infrastruktur dalam penelitian ini antara lain, kebijakan dalam penetapan trase jalur kereta, penetapan lokasi, serta kebijakan dalam penataan ruang yang memberikan peluang dalam pembangunan jalur kereta api. Disamping itu, terdapat kebijakan PSN yang semakin membuat pelaksanaan pengadaan tanah menjadi mudah dan cepat. Di sisi lain adanya perlindungan $\mathrm{LP}_{2} \mathrm{~B}$ untuk tidak dialihfungsikan merupakan jaminan tersedianya lahan pertanian guna mendukung ketahanan pangan, baik untuk generasi sekarang dan yang akan datang. Di Kabupaten Boyolali adanya konflik kebijakan terdorong oleh adanya kekuatan dari para pemimpin di daerah dalam mempersepsikan kebijakan pengadaan tanah dan kebijakan PLP2B. Aturan yang telah dibuat dengan jelas dan rigid dalam melindungi keberadaan $\mathrm{LP}_{2} \mathrm{~B}$, namun adanya kekuatan dari pembuat kebijakan dalam mempersepsikan kebijakan membuat alih fungsi untuk pembangunan infrastruktur lebih diutamakan. Dengan adanya alih fungsi pada $\mathrm{LP}_{2} \mathrm{~B}$ untuk pembangunan infrastruktur, menunjukkan bahwa kepentingan umum untuk pelestarian seperti LP2B kalah dengan kepentingan umum untuk pembangunan infrastruktur. 


\section{E. Ucapan Terima Kasih}

Pada kesempatan ini penulis menyampaikan terimakasih dosen pembimbing tesis pada Prodi Magister Perencanaan Wilayah dan Kota, Universitas Gajah Mada, Kantor Pertanahan Kabupaten Boyolali dan Dinas Pertanian Kabupaten Boyolali dalam pengumpulan data penelitian.

\section{DAFTAR PUSTAKA}

Amiludin. (2018). Politik Hukum Pertanahan Dan Otonomi Daerah (Kebijakan dan Kewenangan Pemerintah Pusat dengan Daerah Terkait Pertanahan). Journal of Government and Civil Society, 2(No.2, April 2018), 19-32. https://doi.org/10.3100o/jgcs.v2i1.712

Aminah, S. (2015). Konflik dan Kontestasi Penataan Ruang Kota Surabaya. Masyarakat jurnal Sosiologi, 20(No.1, januari 2015), 59-79.

Anggalini, T. D. (2018). Studi Kinerja Implementasi Kebijakan Pengendalian Lahan Pertanian Pangan Berkelanjutan (PLP2B) di Kabupaten Gunungkidul. UGM.

Aprildahani, B. R., Hasyim, A. W., \& Rachmawati, T. A. (2017). Motivasi Petani Mempertahankan Lahan Pertanian di Wilayah Pinggiran Kota Malang (Studi Kasus Kawasan Perkotaan Karangploso Kabupaten Malang). Journal of Regional and Rural Development Planning, 1(3, Oktober 2017), 258-269. https://doi.org/10.29244/jp2wd.2017.1.3.258-269

Ayu, I., \& Heriawanto, B. (2018). Perlindungan Hukum Terhadap Lahan Pertanian Akibat Terjadinya Alih Fungsi Lahan di Indonesia. JU-ke (Jurnal Ketahanan Pangan), 2(2), 122-130.

Badan Pusat Statistik. (2021, Februari). Kabupaten Dalam Angka 2020. diakses tanggal 26 Februari 2021. https://boyolalikab.bps.go.id/publication/2020/04 /27/47511789805b25d834a4709c/kabupatenboyolali-dalam-angka-2020.html

Badan Pusat Statistik. (2021, Februari). Kabupaten Dalam Angka 2019. diakses tanggal 26 Februari 2021. https://boyolalikab.bps.go.id/publication/2019/o8/ 16/99acc6eoboe4foze5018brab/kabupatenboyolali-dalam-angka-2019.html

Badan Pusat Statistik. (2021, Februari). Kabupaten Dalam Angka 2018. diakses tanggal 26 Februari 2021. https://boyolalikab.bps.go.id/publication/2018/o8/ 16/9a969438ao72865ae2cob368/kabupatenboyolali-dalam-angka-2018.html

Badan Pusat Statistik. (2021, Februari). Kabupaten Dalam Angka 2017.diakses tanggal 26 Februari 2021.https://boyolalikab.bps.go.id/publication/2017/o8/11 da17684b38ead17a21e336d/kabupatenboyolali-dalam-angka-2017.html

Byrne, J., Hughes, K., Rickerson, W., \& Kurdgelashvili, L. (2007). American policy conflict in the greenhouse: Divergent trends in federal, regional, state, and local green energy and climate change policy. Energy Policy, 35(2007), 4555-4573. https://doi.org/10.1016/j.enpol.2007.02.028

Creswell, J. W. (2009). Research Design Qualitative, Quantitative, and Mixed Methods Approaches (Third Edit). SAGE Publication Ltd.

Dewi,A.M.(2019).PerbandinganPengaturanPengalihfungsianLahanPertanianPanganBerkelanjutan(LP2B) Untuk Kepentingan Umum Antara Kabupaten Ngawi dan Kabupaten Madiun. UGM.

Hakim, A. L., Kolopaking, L. M., Siregar, H., \& Putri, E. I. K. (2017). Perebutan Sumberdaya Air: Analisis Konflik dan Politik Tata Ruang. Sodality: Jurnal Sodiologi Pedesaan, Agustus 2017, 81-91. https:// doi.org/10.22500/sodality.v5i2.17901

Hakim, N., Murtilaksono, K., \& Rusdiana, O. (2016). Konflik Penggunaan Lahandi Taman Nasional Gunung HAlimun Salak di Kabupaten Lebak. Sodality: Jurnal Sodiologi Pedesaan, Agustus 2016, 128-138.

Iqbal, M., \& Sumaryanto. (2007). Strategi Pengendalian Alih Fungsi Lahan Pertanian Bertumpu pada Partisipasi Masyarakat. Analisis Kebijakan Pertanian, 5(No.2, Juni 2007), 167-182. https://doi. org/10.21082/akp.v5n2.2007.167-182 
Lisdiyono, E. (2008). Legislasi Penataan Ruang: Studi Tentang Pergeseran Kebijakan HukumTata Ruang Dalam Regulasi Daerah di Kota Semarang. Universitas Diponegoro. (2014). Pengadaan Tanah Untuk Kepentingan Umum Implikasinya dengan Alih Fungsi Lahan dan Penataan Ruang. Media Hukum, XXIV(No. 1, Januari-Juni 2014), 17-33.

Matland, R. E. (1995). Synthesizing the Implementation Literature: The Ambiguity-Conflict Model of Policy Implementation. J-PART: Journal of Public Administration Research and Theory, 5(2), 145174. https://doi.org/10.1093/oxfordjournals.jpart.a037242

Nugrahani, R. (2019). Dinamika Iplementasi Kebijakan Penetapan Lahan Pertanian Pangan Berkelanjutan $(L P 2 B)$ di Kecamatan Sewon, Kabupaten Bantul. UGM.

Palupi, L. D. (2017). Implementabilitas Lahan Pertanian Pangan Berkelanjutan di Ngaglik, Kabupaten Sleman, Kajian Opportunity Cost dari Hak Properti Lahan. UGM.

Rachmadiansyah. (2019). Implementabilitas Insentif Dalam Perwujudan Lahan Pertanian PAngan Berkelanjutan $\left(\mathrm{LP}_{2} \mathrm{~B}\right)$ di Godean Kabupaten Sleman. UGM.

Syifa, A. (2017). Dampak Pengadaan Tanah Untuk Pembangunan Bandara Internasional Jawa Barat (BIJB) Bagi Masyarakat Pedesaan (Studi Kasus Desa Sukamulya Kecamatan Kertajati Kabupaten Cirebon). Empower: Jurnal Pengembangan Masyarakat Islam, 2(2), 25. https://doi.org/10.24235/ empower.v2i2.4636

Weible, C. M., \& Heikkila, T. (2017). Policy Conflict Framework. Policy Sciences, 5o(2017), 23-40. https:// doi.org/10.1007/s11077-017-928o-6

Zulfikar, W. (2017). Dampak Sosial, Ekonomi Dan Politis Dalam Pembangunan Bandara Udara Kertajati Di Kabupaten Majalengka. Jurnal Caraka Prabu, 1(No.1, Juni 2017), 58-77. https://doi.org/10.24198/ sosiohumaniora.v19i3.12103 